
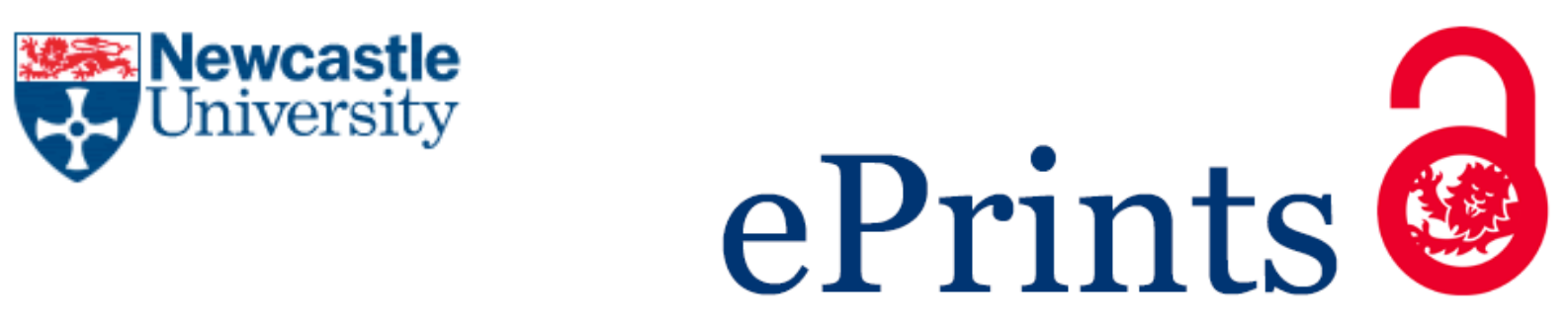

Abdullah S, Gray TS, Clough E.

Clientelism: factionalism in the allocation of public resources in Iraq after 2003.

Middle Eastern Studies 2018

DOI: $\underline{\text { https://doi.org/10.1080/00263206.2018.1444607 }}$

\title{
Copyright:
}

This is an Accepted Manuscript of an article published by Taylor \& Francis in Middle Eastern Studies on 14/03/2018, available online: https://doi.org/10.1080/00263206.2018.1444607

Date deposited:

$15 / 03 / 2018$

Embargo release date:

14 September 2019

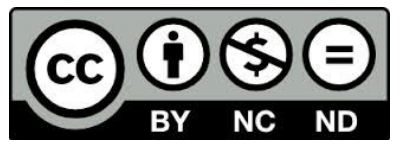

This work is licensed under a

Creative Commons Attribution-NonCommercial-NoDerivatives 4.0 International licence 
Sarwar Abdullah ${ }^{1}$, Emily Clough ${ }^{2}$, and Tim Gray ${ }^{2}$

${ }^{1}$ Department of Politics and International Relations, School of Law and Politics, University of Sulaimanyah, Kurdistan

${ }^{2}$ Politics, School of Geography, Politics and Sociology, Newcastle University, UK

Dr Sarwar Abdullah s.abdullah@ncl.ac.uk

Dr. Emily Clough Emily.clough@ncl.ac.uk

Prof. Tim Gray tim.gray@ncl.ac.uk

\section{Clientelism: factionalism in the allocation of public resources in} Iraq after 2003

This paper examines clientelism in Iraq as a case study of one form of corruption. Iraq is an unusual case of corruption, because a key feature of Iraq's corrupt environment is an institutionalized factional political system based on sectarian quotas. The paper explores the many links between clientelism and political factionalism, discussing whether clientelism arose because of factionalism, or whether factionalism merely determines the ways that clientelism currently operates in Iraq. Using fieldwork data, the findings show there are two distinct levels of clientelism in Iraq, both of which are linked to political factions: the individual level; and the organizational level. First, clientelism at the individual level entails the elites of many political factions regarding "money politics" as a means of influence in Iraq/ Kurdistan by buying people's affiliations and thereby governing people. Second, clientelism at the organisational level entails that the spoils of political office are shared out among the elites of the political factions in a proportionate fashion. The paper concludes that clientelism is a form of political rather than economic corruption; and that while there may be some immediate value in clientelism, its long-term harm outweighs its short-term value.

Key words: clientelism, oil-rents, corruption, Iraq and sectarianism.

\section{Introduction:}

Despite the pervasiveness of clientelism in Iraq for centuries, from feudalism to Ba'athist party rule and the current post -2003 sectarian government, there has been no published study of clientelism in Iraq. Yet clientelism has had, and continues to have, a significant effect on Iraq's economic and political system. For example, it has discouraged the government from providing public goods based on merit and capacity through fair competition; it has increased inequality in accessing state resources; and it has enabled rulers to stay in power by allowing them to stage elections in which competition is stifled (Stokes, 2007; Hicken, 2011; Hilgers, 2012). It is argued that despite the establishment of the new Iraqi government after 2003 ending one-party rule that had prevailed for over 50 years, clientelism has persisted along sectarian and party lines directing public funds for the benefit of particular groups. 
In this paper, I will consider, first, what can be accounted as clientelism in Iraq, and due to the lack of consensus on the term, I will define it and justify why such a definition is appropriate to Iraq. I have identified five important features attributable to clientelism diffuseness, longevity, obligatory, collective/dyadic, and reciprocity. Second, using data from fieldwork, the paper will construct a typology of the patterns of clientelistic ties found in Iraq that focuses on the new form of Iraqi government and its allocation of state resources. This typology divides clientelism into two levels: the individual and the organisational. The paper will conclude that clientelism is a political rather than an economic form of corruption, and that although clientelism in Iraq is fundamentally harmful in the long term, there may be some short-term value in it.

\title{
The context of clientelism in Iraq
}

\author{
"Clientelism cannot be meaningfully considered apart from the setting in which it \\ exists. The forms which it takes depend to a considerable extent on the structure of \\ the society and on the political system in which it operates" (Lemarchand and \\ Legg, 1972:156)
}

What can be accounted as clientelism in Iraq? Clientelism has always existed in Iraq in one form or another. Political transformations such as the replacement of the Baath party in 2003 as a result of the US-led invasion, did not end clientelism, but only changed its form. During the previous 40 years, the Baath party as an engine of power had built a strong centralised patronage system over its population, controlled by a restricted inner circle of Saddam's close associates (Tripp, 2001). Iraqis assumed in 2003 that elections and the new leaders in the government would bring about democracy; civil society would be autonomous; and political activities would be free and open for all. But the kind of democracy and elections that emerged did not lead to the death of clientelism, but to a new form of clientelism based on sectarian and partisan lines - muhassasa - which has operated in a wider manner than the centralised patronage system did during the time of Saddam.

The question arises as to whether or not this new form of clientelism in Iraq requires us to change our definition of clientelism. The concept of clientelism has been used universally by many scholars, but it is hard to find a single definition to fit all contexts. While there is agreement on a broad generalisation that clientelism is an exchange relationship for obtaining political support, entailing selective access to resources for those within the bargaining system and the exclusion of others from that access - i.e. it is a quid pro quo between groups or individuals of unequal political and economic standing - the type of inequality of the 
partners may vary from context to context depending on the extent to which the political system is democratised and the resources are widely distributed. Many scholars have focused on the particular contexts of clientelism: for example, (see: Eisenstadt and Lemarchand 1981; Grzymala-Busse 2008; Hicken 2011; and Hilgers 2012). It seems that scholars are no longer interested in debating broader definitions of clientelism, preferring to leave the task of definition to local contexts because of the difficulty of arriving at a single precise definition.

Nevertheless, although there may be a lack of agreement on the precise definition of clientelism (beyond that of saying that it is an exchange relationship for obtaining political support), there may be agreement on the features by which the clientelism relationship can be identified and distinguished from other social ties. I have suggested five such featuresdiffuseness; longevity; obligatoriness; collective/dyadic; and reciprocity (Muno, 2010; Hicken, 2011). The next five subsections, will illustrate how these five characteristics can be found in Iraq.

\section{Diffuseness}

Much of the literature contends that clientelism focuses on single material transactions, such as offering jobs or material rewards including land, in exchange for votes (Vicente and Wantchekon, 2009; Hilgers, 2012). However, the relationship between citizens and political parties may cover a wider range of exchanges than single transactions, including land, jobs, houses, and protection, in return for which clients' express loyalty and support as well as promising votes for the provider. Some scholars have described these wider ranges as a diffuse feature of clientelism ties. According to Eisenstadt and Roniger (1980: 49), clientelism is often described as diffuse in nature, because different kinds of resources and promises have characterised it. The relationship covers a wide range of potential exchanges, and so diffuseness is one of the distinct qualities of the relationship between patrons and clients (Scott, 1972: 95). In post-2003 Iraq, this has been evident in the sectarian and partisan governmental system based on muhassasa. Through this system, party affiliations have replaced entitlement based on merit. The parties' capacity to use public funds for clientelistic purposes depends on the extent to which state funds are allocated according to muhasassa and partisan logic. The allocation of public funds does not come from citizens' taxation but from oil rents. The resources exchanged include economic goods, political support, loyalty, votes, and protection on the one hand, and promises of solidarity and loyalty on the other. 
Thus, the diffuse nature of clientelism ties should be considered as part of the definition of clientelism in the context of Iraq.

\section{Longevity}

The literature suggests that modern clientelism is characterised by short time spans such as material transactions offered some days before elections, offered to citizens in return for their votes (Schaffer, 2007; Nichter, 2008). But the literature also refers to the continuous nature of the relationship between patron and client. According to Kitschelt and Wilkinson (2007: 8), politicians gain confidence in the viability of their transactions by iteration, or a gradual build-up of the relationship. Some modern clientelistic relationships are not necessarily inherited, but still some inherited elements may remain (Muno, 2010). This feature distinguishes clientelism from other exchange relations such as bribery, which are usually short-lived, where neither party has a strong desire to interact in the future. In Iraq, this longtermness has an important implication for clientelism in that the exchange is based on public sector jobs which are usually characterised by longevity.

\section{Obligatoriness}

Clientelistic relations are generally seen as voluntary. At any rate, the connection between patron and client can officially be abandoned voluntarily (Eisenstadt and Roniger, 1980: 50). But what makes the clientelistic relationship continue for a long time if it is voluntary? According to Muno (2010) this is because ending such clientelistic connections, like other connections, entails certain costs. The question is whether such costs would be high enough to deprive 'voluntary' of any recognisable meaning (Hicken, 2011). According to Stokes (2007: 608-609), there may be fear of retaliation if the connection is severed. Perhaps both sides would have to pay some costs for exiting such connections: from the client side, they may lose their benefits such as jobs; from the patron side the cost may be loss of credibility they may not be trustworthy anymore and could not mobilise their clients in case of need (Muno, 2010). So, one can argue that because of such costs, both clients and patrons may have to comply with clientelistic connections: the relationship is no longer voluntary but to all intents and purposes obligatory.

In the past, under the regime of Saddam Hussein, patronage was based on one-party rule and a long-standing relationship of domination by one family and loyalty to one political party in power - the Ba'athist party. This form of centralised patronage was authoritarian, in which 
the relationship endured by threat and coercion. Clientelism was used as a tool of social control throughout the rule of the Ba'athist party between 1968 and 2003, and was therefore more obligatory than voluntary. But today, this kind of coercion no longer exists in Iraq, and instead, clientelism is operating in a wider way than the past because, ironically, it has become democratised based on muhasassa. This system still involves monitoring clients' behaviour by different groups in power during election times, to force client to carry out their commitments. But political parties do not have such power as Saddam Hussein had to compel clients to stick to their commitments. In many cases, clients have lost their jobs when they have voted for other parties, but they are not forced to leave Iraq, as under Saddam's regime. Nevertheless, it would be hard to consider such clientelism under the muhasassa system as totally voluntary: clientelism based on muhasassa is not completely free from force, and the voluntary element is not absolute.

\section{Collective/dyadic}

A dyadic exchange of particularistic favours between two individuals is the traditional sense of patron-client relationship, whereas the modern version broadens the exchange to include collective exchanges (Montambeault, 2012: 99-101). The dyadic element lies in the fact that clients have to work for, or give solidarity and support to, patrons in exchange for the provision of goods, services and jobs (Muno, 2010). Landé (1983: 443) held that dyadic relationships are sometimes elusive, in that the relationship is usually informal, and not subject to record. By contrast, when allegiance is expressed by clients towards a political party and state actors, it has a collective rather than dyadic character. In recent literature, the central debate revolves around whether the clientelistic ties in a muhasassa system such as Iraq are dyadic or collective. In fact, they are both: both dyadic and collective ties can exist in muhasassa and partisan forms of clientelism. Dyadic exchanges involve personal one-to-one connections with politicians who aim to be elected and re-elected, and citizens who are involved in bargaining for accessing public privileges. Collective exchanges are involved when political leaders use the popularity of the party platform to garner support within organisations such as tribes, and NGOs, by giving them economic incentives and exploiting their affiliations at times of elections. Thus, in the case of Iraq we need to add collective bargaining to individual bargaining where groups of actors trade allegiance in return for benefit from access to the public resources.

\section{Reciprocity}


The fifth feature of clientelism in Iraq is reciprocity. According to Stokes (2007: 605), a clientelistic tie is a quid pro quo or reciprocal relationship in which the client complies by providing political support to the patron. Muno, (2010) argues that clients have to work for, or give solidarity and support to, patrons in exchange for the provision of goods, services and jobs.

To sum up, the above discussion shows that the definition of clientelism centres on the trading of state funds by political parties in return for political support. In the case of Iraq, such buying of affiliation is characterised by a clientelistic relationship containing five features -diffuseness, longevity, obligatoriness, dyadic/collective, and reciprocity - and this identifies the core concept of clientelism in Iraq. The next section shows where we can find these five characteristics of clientelism in Iraq.

\section{Patterns of clientelistic ties in Iraq}

The aim of this section is to explain the many ways in which clientelism operates in Iraq and to investigate why this kind of clientelism occurs there, and why it can be considered as clientelism on our definition. The discussion is based on the perceptions of clientelism expressed by elite interviewees and focus group members during fieldwork conducted in 2014-2015. The findings presented here reveal two kinds of clientelistic exchanges: first is the buying of affiliation at the individual level; second is buying the support of groups rather than individuals.

\section{Buying individual political affiliations}

Data show that politicians are involved in clientelism at the individual level in the following three ways: public appointments; ghost jobs; and short-term perks and retirement pensions.

\section{Public appointments}

The distribution of public sector jobs in Iraq through clientelism has taken a new form, totally different from the past as a result of the sectarian government. It was confidently predicted that the post-2003 political transformations and elections in Iraq would bring a replacement of the particularistic relationships such as the patronage network in the former Iraqi regime (Le Billon, 2005) by a new state-citizens relationship based on merit in selecting people for public sector jobs. However, the sectarian and partisan form of government led to political 
leaders violating the principle of equal access to state employment, and inequality in obtaining state jobs persisted.

A former Kurdish MP in the Iraqi parliament said:

"... the former prime minster [Nuri al-Maliki] when he submitted the budget that comes from the government, put too much money into the Ministry of Defence and the Ministry of Interior - more than what should be [needed] for the security sector. For instance, within that security sector there are 10,000 employees and the standard for employing those people is not loyalty to the government but loyalty to a particular sect, a particular religion, a particular component, a particular party and within that party to a particular leader. These 10,000 security people are purely those people who are loyal to his party".

As a current Kurdish MP in the Iraqi parliament said of Prime Minister Maliki, "He obtained millions of votes at the last election because before the election he... employed many people in his party i.e. 10,000 in defence and interior ministries".

Giving public sector jobs is also a way to build relationships more broadly between citizens and parties whereby parties can control society. As a Kurdish independent commentator said, "spending the public budget in political ways... buys loyalty... in Iraq, more than five million people have taken salaries from different government departments. The main aim of these employees is to capture people or to calm down people from rebelling against elites in power". So the budget fuels fiefdoms owned by various sectarian and partisan leaders who use it for political purposes. The power of the political parties has become a channel to divert public resources to sectarian ends.

A current Kurdish MP in the Iraqi parliament said that clients endeavour to improve their lives by obtaining public sector jobs through being affiliated to political parties in power. He notes that "the public employment in Iraq is now more than 15\% of whole of the population". The problem is that, as argued by a NGO member in Baghdad, many of these appointees are unqualified for public office because they lack the minimum requirements of education and experience for such positions.

Although such clientelistic arrangements seem to be voluntary in that they are not necessarily the result of exploitation and manipulation, if somebody is appointed by a political party they 
have to vote for the party who has given them the job, otherwise they lose their job. This has been observed in the security and police sectors over the last few years. As a member of the NGO's focus group discussion said, "I know many people were working in the police and security forces who did not vote their political parties in power, but they lost their jobs". According to an official in the Kurdistan region, "their life depends on the resources parties are provided for them so they have to be committed to the parties' politics". A former official in Kurdistan government who now leads a personnel consultancy company, said "the parties in power threaten people by saying: you have to be aware that I provide your salaries; if you do something unpleasant towards the party, I will cut your salary".

This shows how clientelism in Iraq is not really voluntary, by contrast to the literature which highlights the voluntary feature of clientelism (Muno, 2010 and Hicken, 2011). In Iraq, such reciprocity contains an obligatory connection between two parties. Monitoring by parties' organisations to ensure that clients comply with the parties' strategy in election time or else they will lose their salaries, makes clientelism more of a dyadic relationship or one-to-one connection than a collective one. Moreover, as long as the exchange is based on public jobs, it can be described as a longevity connection between two parties. All this indicates that such exchange relationships cover the five features of clientelism.

One reason for the perpetuation of this clientelistic system of job allocations is that, as the journalist focus group discussion made clear, without a connection with a political party, citizens would find it difficult to obtain jobs. A current Kurdish MP in the Iraqi parliament argued that party linkage is a precondition for being given public sector jobs, and there is little prospect of obtaining jobs in the private sector. Iraq had long been a rentier and socialist country, where the private sector was small and so the public sector was the only choice for employment. A senior Iraqi official, said, "these huge levels of employment in the public sector are not recent to Iraq... the private sector did not exist before 2003 and we do not have a very strong private sector to employ people there". Likewise, a member of the journalist focus group said that:

"Iraq was a socialist system till the overthrow of Saddam.... after 2003 in Iraq we do not know whether Iraq has adopted socialism or capitalism... and we live under the old socialism rules in which all things are run by the government such as health, education... and the private sector is not involved in running any of these sectors. 
Therefore, all people try to find opportunities and work in the public sector".

The main reason for the continuation of clientelism in Iraq after 2003 is the development of the system of muhasassa in Iraqi politics, ministries and institutions, which was inextricably linked to sectarian quotas. As a former Sunni MP said, there was a huge increase in the number of political appointments in the Iraqi public sector because "al-muhasassa is a fertile ground for this employment." An MP formerly on the Integrity Commission, said "that in Iraq the political parties coming into government hand out many positions from the cleaners up to the post of minister".

In the Kurdistan region, the system of political appointments is based only on party divisions, not ethno-sectarian divisions. A former MP from the Kurdistan parliament, claimed that, "In Kurdistan, there is no issue related to the ethno-sectarian division [the majority in Kurdistan are Kurdish speakers], but here there are divisions based on the political parties between the Patriotic Union of Kurdistan [PUK] and Party Democratic of Kurdistan [PDK]. In the past few years to buy votes in the general election the political parties did everything such as providing public sector jobs these all happen by both parties in power".

\section{Ghost jobs}

Another aspect of sectarian and politically-oriented appointments, is jobs through 'Ghosts' (al-Fazhia in Arabic), a term which has recently become notorious in Iraq. In his first speech as Prime Minister in the Iraqi parliament, Haider al-Abadi said, 'In four Iraqi army sections, which included 100,000 soldiers, 50,000 were unreal and called ghosts (al-Fazhia) (A current Kurdish MP in the Iraqi parliament). The term 'ghost' has two meanings: real and imaginary. The 'real' ghosts exist in the real world as people who draw salaries but do little or no work: the 'imaginary' ghosts do not exist in the real world but are fictitious names used to generate money for their inventors. For example, a former commissioner in Baghdad mentioned a case related to Mushan al-Jburi (a current Sunni MP): "he was in charge of an oil pipeline between Kirkuk and Turkey for a few years in post 2003. Al-Jburi was responsible for protecting the oil pipeline but he listed 14,000 soldiers and he took the regular salaries of 14,000 soldiers, however, practically, there were only 3,000 soldiers there". 
Typically, 'real ghosts' are people on the army payroll who draw salaries but do not take part in any military action. Former Prime Minister Maliki built what is called al-Isnad (supporters) for the Iraqi military forces, but these supporters often sat at home, costing 500,000 Iraqi dinars (roughly equivalent to US\$450) each per month. General David Petraeus (then head of the US General Forces in Iraq) launched an initiative to face al-Qaida called alSahwa (awakening), but commenting on this initiative, a former commissioner at Baghdad said that ' $3 / 4$ of the al-Sahwa army were found to be 'troops in the sky' in Iraqi terms;' i.e. 'ghosts'. An investigation by the Chief of the Armed Forces found that US\$14 million was spent each year on 'real' ghosts".

Ghosts are not confined to the defence sector: according to a current Kurdish MP in the Iraqi parliament "the number of ghosts in the interior ministry are 75,000 and in the municipality of Basra there are 5,000 ghosts and in the municipality of Baghdad many ghosts were disclosed. During four months of investigation more than 120,000 ghosts have been found in different Iraqi institutions". Ghosts also exist in the Kurdistan region, as a high commissioner in the Kurdistan region said: "in Kurdistan there is talk of 100,000 people in one day going to their office in order to take their salaries and after that they do not go to work at all... Some talks of about 50,000 and some 100,000 and some talk of around 200,000". In the last few years, some politicians have obtained many votes through providing ghost jobs even in areas where such politicians are not popular. For example, the former prime minister personally benefitted to the tune of millions of votes.

Such allocations through ghost jobs may not cover all the five features of clientelism found in the literature. For example, ghost jobs lack the one-to-one connection of clientelism, because although we know one side of the bargain (the patron), the other side (the ghosts or clients) are hard to identify and may be fictitious. It is also true that ghost jobs may mean little more than material goods rather than being an exchange relationship for political purposes which is mainly what clientelism is about. Such connection through ghosts can be classified as a form of buying of groups of loyalties because it is characterised also by collective relationship i.e. groups connection with the parties. Nevertheless, this kind of relationship exchange can be labelled as clientelism because it manifests all the other features - diffuseness, longevity, obligatoriness, y, and reciprocity between two parties.

The negative impact of ghost jobs is severe. Not only is it a gross waste of public resources, it can undermine the effectiveness of military security. For example, in August 2014, part of 
Iraq was occupied by ISS, and as a Kurdish MP in the Iraqi parliament said, "investigating the reasons behind the collapse of the Iraqi army, ghosts had a huge impact on lowering the capacity over 2-3 days of the Iraqi military force regarding large ISS controlled areas". On the other hand, some respondents, including an Iraqi high commissioner, have claimed that the ghost issue could be seen as a means of "reconciliation between Shia and Sunni communities" because it encourages al-Isnad (supporters) and al-Sahwa (awakening) from Sunni tribes to feel secure enough to become a part of the Iraqi forces in fighting al-Qaida.

\section{Short-term perks}

In addition to these public appointments and ghost jobs, there are short-term perks such as gifts of money or meals before elections. As long as sectarian affiliations exist, individuals vote for their parties who are from either Shia, Sunni and Kurds dominated areas. However, because of multiple political groups in each area, there are divisions and subdivisions within each sectarian group. As a former Kurdish MP in the Iraqi parliament stated that "there are many rival groups within a single ethnic or religious background. For example, within the Shia there are many political groups and this is also true for Sunni and Kurds; it is hard to say that one single political party can reflect the reality of one component". In this situation, although ethnic and religious affiliation or identity is manipulated by the political elites (Eifert et al., 2010), voters support different candidates within their ethnic or religious group who are from their own communities - what is called in Arabic ibn al billad (son of the community) - and they may choose candidates who deliver services to their narrow local community (Lust, 2009: 127). So citizens not only support ethnic or religious sect parties, but they prefer candidates within those parties who are affiliated to their family or tribes, or who provide some immediate gifts. For example, in poor areas, the political parties provide transportation, entertainment, meals, clothes, and cash and make recommendations to the voters about how to use their ballots (Fieldwork notes, 2014-2015). Another former Kurdish MP in the Iraqi parliament reported some candidates before an election "providing fried chicken". A former senior official (now retired) in the Kurdistan region referred to "[political parties in power] giving cash [to voters] some days before elections". Personally, I observed this in the region many times. This kind of inducement to vote for an ethnic segment of a political party was encouraged by the changes in the electoral rules in 2005 and 2013 allowing voters to choose between different candidates within a political party. Because it is not long-term, this type of the exchange may seem simply vote-buying, but some writers have 
asserted that vote-buying is a durable relationship between two sides and helps politicians, in particular, in oil rich countries, to stay in power (Andersen and Aslaksen, 2013), and therefore is a kind of clientelism (Vicente and Wantchekon , 2009).

The fact that short-term perks are distributed by many parties' organisations in a variety of forms (including goods, services, and cash) during days before and after elections (my fieldwork notes 2014-2015), indicates the diffuseness of this clientelistic transaction. Brokers monitor voters' behaviour, and clients may be afraid that if they fail to honour their electoral commitments, parties in power may ask for the return of the gifts that they took before elections. This illustrates the embedded reciprocity exchange in clientelism. However, the short-term perk lacks the collective/dyadic feature connection of clientelism, and so it could be labelled not purely, but significantly, clientelism.

\section{Retirement pensions}

The fourth kind of individualistic clientelism in Iraq involves retirement pensions. Clientelistic retirement pensions take three different forms. The first form is people who obtain high rank retirement pensions. For example, a Kurdish MP in the Iraqi parliament explained that "in Kurdistan there are 1,026 people with the rank of retired minister, vice minister or general director, even though there have only been six successive cabinets. The number of ministers receiving retirement pensions exceeds the total number of members of these cabinets, and inside this list there are retired people with the rank of ministers who have never held the position of ministers at all'. Another MP in the Kurdistan parliament reports "404 retired women with high military ranks, none of whom has been involved in military service". According to a former commissioner in Baghdad "people may be employed for 1-5 days and then retire, based on their affiliation to a specific political party."

Such rewards may make the retired people renew and continue their loyalties to the parties, and this why we define such retirement pensions as clientelism - because the purpose of the pension, according to a Kurdish independent commentator, is "continuing in their support of the parties in power", thereby embedding a longevity relationship between parties and their members. Through such retirement pensions, parties can secure their clients' commitments to the parties' interests until the very end of their lives. Such connection can be marked by reciprocity as well, and there may be a dyadic connection between retired people with political leaders, if they are both from the same sect or the same political party. The 
relationship may not be directly face-to-face, but the retired people may have a strong connection based on respect and meeting leaders' demands when necessary. Hence, such retired links based on secure loyalties are closer to clientelism than any other connection.

From the four instances of individualistic clientelism identified above, we can conclude several points:

First, individualistic clientelism could be considered a means of involving more people in politics and raising their awareness of public policy, because in a variety of ways, many people have become incorporated into the political system, though this is not to say that all citizens are now meaningfully integrated within this clientelistic system.

Second, individualistic clientelism can be considered as a means of re-distributing state resources, since, as an MP from a prominent party in power in the Kurdistan parliament, said, "People do not have opportunities to work and there are young graduates with no job options. The private sector is not so strong here." Although the receivers must obey the providers, this does not necessarily mean slavery (Muno, 2010). Indeed, it could be argued that clientelism can bring in to the political system many marginalised people who are excluded from the benefit of state resources. Moreover, such clientelism could be seen as a means of preventing people from engaging in the violence that sometimes erupts when they feel deprived of the benefits of public resources.

However, third, my view is that, regardless of these benefits, individualistic clientelism has been very harmful to the way democracy has functioned in Iraq, undermining accountability. Sectarian political parties capturing citizens by using public wealth to buy political affiliations that benefit the parties in power, undermine the principle of democratic decisionmaking. Such huge manipulation of public appointments by parties means the repression of critical voices on corrupt state decisions. As a Kurdish independent commentator said "If people take jobs based on buying affiliations ... this is blunting their criticism of the government". Another official in the Kurdistan region raised the danger of ending up like Gulf countries which "lack space for criticism" and the rulers stay in power for a long time. This has produced over the last decades what is called freakery in Arabic or "Al-Fahula", where "one voice controls the others" (NGOs focus group's discussion, also confirmed by a Kurdish MP in the Iraqi parliament), whereby the entire society becomes attached to the parties in power. Instead of voting being a means of holding politicians to account, it 
becomes a means whereby politicians hold citizens to account for their pledge of electoral commitment to the party. Such clientelism allows some politicians to survive in power until they die.

Fourth, the question may be raised whether such individualistic clientelism is corrupt when it is not illegal. The reason why individualistic clientelism is corrupt is because it is formed to promote mutual benefit between two parties at the expense of public funds (Kawata, 2006: 12-14). In other words, people who are involved in a clientelistic exchange relationship gain a mutual benefit which is private, and this means privatising the public interest for a particular segment of the community. As Hutchcroft (1997) put it, individualistic clientelism is 'particularistic advantage' and the implication is that this clientelism relationship will harm the public interest, and is therefore corrupt, whether or not it is legal.

Fifth, individualistic clientelism results in a waste of public resources, because it creates a situation of over-employment and inequality in accessing state resources, and of unqualified people in the bureaucracy. Furthermore, it undermines the capacity of the government to allocate capital for investment. As a current Kurdish MP at the Iraqi parliament, noted: "In Iraq..., nearly $70 \%$ of the public budget went to operational aspects in the form of the salaries, and only 30\% went to investment aspects, and Kurdistan was the same in this regard...This is because of the huge number of people employed in the public sector."

In summary, four kinds of benefits were exchanged for political support: public sector jobs and retirement pensions are full-blooded clientelism; whereas ghost jobs and short-term perks are partially clientelistic. In the next section, we discuss clientelism that occurs at the organisational level, including buying the support of groups rather than individuals.

\section{Buying the support of organisations}

Besides buying the political affiliation of individual people, there are forms of political exchange in Iraq that involve buying the support of groups rather than individuals, and the use of a wider range of inducements than jobs and welfare benefits. The three subsections below draw primarily upon views expressed by interviewees and focus group discussants during 2014-2015, supplemented by my observations and reflections in the field.

\section{Buying support from NGOs}


The importance of NGOs for the parties in power is that NGOs can provide both short-term and long-term support. NGOs represent a new organ for political parties, and parties can capture them through offering funding. A member of the NGOs focus group, raised the issue of funding and said, that "between 80 and $90 \%$ of the NGOs are part of the parties in power, since without financial support from the parties in power, these NGOs cannot afford to pay the rents of their offices." Funding opens up the prospect of long-term and sustainable connections between NGOs and parties in power, and long-term connection is a feature of clientelism. The importance of funding to NGOs is that it is the only way whereby they can survive to carry out their everyday tasks.

Unlike NGOs in other countries, NGOs in Iraq have little desire to regard themselves as independent of political parties. This is clearly observable in many Iraqi elections and rallies where NGOs publicly support their sponsoring parties. The NGOs focus group argued that all of them [NGOs] live by funds from the PUK and PDK parties in the Kurdistan region. Indeed, a considerable amount of NGOs' time and energy was allocated to make connections with the right political actors at state level or leaders of political parties because this connection secures their funding. A Kurdish independent economic commentator in the Kurdistan region said that it is common practice for officials or figures from political parties to become heads of the NGOs:

"The parties put their members in the top positions of these organisations ... these organisations are partially or fully a part of the party - for instance, organisations for students- because parties finance these organisations and at the end these organisations cannot do anything against the government. There is no organisation in this county without political and financial links with parties. These organisations become a semi-public sector. Instead of expressing their own independent voices and interests... for monitoring the government's public policies, they are already a part of the political parties in power. The parties often finance organisations in their programme and organisations support government. How could such organisations speak against the government? In this country almost all NGOs are run by political leaders. These organisations should demonstrate the reality of the society, in contrary; they tend to cover these realties. They take money and they are member of the parties in power and they can do nothing against parties in the government".

NGOs have become very effective channels through which parties can gather support and solidarity at the national and local levels, because they have members on the ground who can 
look for votes, alliance, and support. Also, NGOs can monitor their members' voting behaviour, and if members do not follow the NGO's collective decision, they are sacked from their jobs. Two such cases were revealed by a member of the NGOs focus groups: one of the cases related to himself and the other related to his friend. This indicates the obligatoriness of the reciprocity exchange between parties and NGOs. The great value to NGOs of their affiliation to political parties is not only the securing of funds, but also their enhanced status in the eyes of the elites.

However, this does not necessarily mean that all NGOs in Iraq are subject to this connection. For one thing, the study covers only part of Iraq (the area of the fieldwork) and may not be representative of the whole country. For another thing, some NGOs have independent political, social and economic purposes and have some NGO members who are politically unbiased in their decisions during the time of elections.

\section{Buying support from small parties}

Another organisational level connection is with smaller political parties. As one interviewee, who was an MP from a party in power for many years in the Kurdistan region, said, "Buying loyalty is not only related to ordinary people, but also the big political parties buying the smaller ones". This kind of relationship indicates that a new form of political exchange has been established. A journalist in the journalists' focus group discussion who had personally investigated this issue, reported his findings thus:

".... I published a document in which the Minister of Finance from the PUK party clearly stated that: 'we decided to increase the budget of the five political parties'; the formal letter was sent to the high office of the PUK party. So I published this document, and everyone understands that all small parties take the money directly from the PUK [in Kurdistan]. But they actually got the money from the Finance Minister [public money]. So the process is like this: the Minister of Finance gives money to the high office of the PUK party. It is difficult to identify what they meant by small parties, but I got the impression that it includes parties from different minorities or from other groups who have got only one or two seats in the parliament, and they talked about the small parties in the Kurdistan region rather than in the whole of Iraq, and from there the small parties take the money. So the small parties understand that the money is given by the bigger parties, so they have more commitment with the PUK/PDK 
parties' policies. This is the process of buying small political parties".

Offering public money to small parties is intended to encourage small parties to form alliances with the political parties in power. Political parties in power make it clear that offering such funds is contingent on obtaining political support, thereby putting small parties in a place where they would not rebel against them. Such a connection also prevents small parties working together to achieve effective representation. This is an example of clientelism in that the purpose of the fund is to build reciprocity which enables parties in power to maintain the status quo.

For the small parties, the main advantage of these deals with the major parties is obtaining money. This has led to their description as 'political shops' by a member of the NGOs focus group, who said, "currently we call these small political parties political shops". Just as there are retail shops doing commercial business, so there are political shops that do political business. However, interviewees and focus groups did not provide many details about this exchange relationship, and there were disagreements between them over what was being exchanged and for what purpose. Nevertheless, based on their testimonies we can draw two conclusions. First, buying affiliation here is not related to the buying of votes of members from small parties in parliamentary elections, but rather to the buying of votes of members of small parties in parliament, because when they get to the parliament the smaller parties have to support their sponsor's parties. A journalist in the journalist focus group elaborated this point thus:

\footnotetext{
"Some small parties from different minorities in the region obtain one or two seats in the Kurdistan parliament but they join up with the big parties. There do not have independent opinions about the issues but they are often meeting with the PDK MPs. Based on that, we called them the special force. MPs from PDK frankly told us that we are 37 MPs but with the special force we become 48 MPs: when they come to the negotiation and vote for a particular law, they told us we are 48 MPs".
}

This process indicates that buying the affiliation of the small political parties is a form of collective bargaining between parties in power and small parties. As long as the small parties honour their commitments to their sponsors (parties in power), the reciprocity exchange can be relatively long-lasting and collective, all features of clientelism. Second, this process indicates that building genuine opposition parties will be difficult. There can be no hope for 
building political watchdogs in the country when not only NGOs but also small parties are so closely linked with the political parties in power.

\section{Buying the support of families and tribal affiliations}

Another organisational level link is related to buying the support of leading religious families. Here the influence of political parties in power may be discerned operating more widely in Iraqi society, extending to the country's traditional tribal and religious family systems. Despite many changes in the structure of Iraqi society because of modernisation, the mental and spiritual make-up of many people has not fundamentally changed. Inducements from a political party to the elders in traditional tribal family groups may be sufficient to persuade all the group's members to give their support to the sponsoring party. There are three types of families: famous families; martyrs' families; and poor families.

On famous families, the most effective mechanism for capturing famous families is to provide them with funding support from the political parties in power. An example of this practice was provided by a member of the NGOs focus group, who argued that in Kurdistan, the misappropriation of public resources is done in a systematic way to support members of well-known families: "we do have a specific type of family who receive regular funds from the government or from the political parties in power."

This form of exchange is based on a promise by the head of the families, and recommendations by elders are apparently effective due to their frequent interactions with their local community. This kind of exchange relationship is not only iterated over a long period of time, but also collectively backed by strong grassroots support of people from tribes, and is therefore consistent with the notion of clientelism. It seems that this kind of exchange between parties in power with some elder's families is far more effective for the parties as social multipliers in generating core party support than those generated through one-to-one connection, i.e. jobs. However, such connection cannot be classified as fully reciprocal because parties cannot impose any kind of punishment on broader members of families for lack of commitment to the parties' candidates in time of elections.

On martyr families, a senior advisor in the Kurdistan region government affirmed that " $W e .$. built many houses for the families of martyrs in different areas in the Kurdistan region, again with oil money." The government, in order to make martyrs' families happy and compensate them, reward them with a wide range of privileges. Although each government has its own 
ways of providing such compensation, in Iraq it includes houses, salaries, land, and scholarships. Such compensation keeps these martyrs' families within the parties' core supporters. My evidence over the last two elections in the Kurdistan region indicates that one opposition party (Goran Party) has increased its votes significantly in areas where many martyr's families live. However, some martyrs' families complained to the media that they were neglected by the parties in power.

This form of compensation seems acceptable in Iraqi society because these families in the eyes of the people deserve help due to their greater sacrifices in the last decades of wars in Iraq. However, a former MP from the Integrity Committee in Kurdistan parliament described the corrupt self-interest entailed in such allocations of public resources: “...the politicians built around one thousand houses for martyrs' families from oil money. Indeed, they did not do this formally as a government service for such family, but the house was considered a gift from the party to such family in order to buy their family's loyalty."

Another targeted demographic is providing help to poor families, though there is a problem of how this allocation worked. According to a journalist investigator in the journalist's focus group discussion, there were questions about whether these benefits ever reached poor families, because the money was distributed via the offices of political parties:

"...when the budget of 2013 was set up, there were tables for the allocation of the budget and a bit of explaining about the spending. There was money allocated for poor families as a social benefit and I personally investigated this money and found that the government money has been distributed in the departments of the political party building. It turned out that members from the political party take lots of money and distribute it to the poor families. As far as I know about this issue, this is a kind of deceit.... I went to the General Director of the Ministry of Social Affairs, and I said why you are distributing money at the political party's branch. He frankly replied that the high official at the top had asked me to do so".

From the above account of instances of connections between parties and organisations or groups, four points can be concluded:

First, by contrast to the one-to-one interactions of individual clientelism, organisational clientelism is characterised by diffuseness, in which a wider range of inducements than jobs and welfare benefits are used. Moreover, the funds and rewards given to the organisations by 
political parties are given not so much to pressurise NGOs or other organisations into adopting a particular voting preference, but rather to persuade as many people as possible to support the political parties in power (Warner, 1997: 537). This indicates that such exchanges are marked by collective bargaining that involves buying the support of whole groups rather than particular individuals. Establishing such relationships with NGOs and other organisations can also be marked by longevity in that the commitments seem to be long-term. This makes the exchange relationship cover most features of clientelism.

Second, this kind of clientelism with organisations provides opportunities for members inside these organisations, who previously spent most of their life enduring dictator regimes, wars and conflicts in Iraq, to engage in the process of learning skills in running civil society. Such contributions helped to educate them in participation, co-operation, and familiarity with the state's laws and policies. Third, however, these clientelistic activities may compromise the political neutrality of NGOs, and change the NGOs and other organisations (e.g. famous families or small parties) from non-partisan to partisan activism.

Fourth, the diversion of public revenue to the large political parties and then to other small parties could be considered the looting of public money, hugely costly to society as a whole. Moreover, it is an obstacle when it comes to building efficient opposition parties or active civil society, because it prevents political leaders from facing any basic challenge to the expansion of their power. NGOs are supposed to be the key organisations to defend the interests of the citizens against arbitrary state actions, but in the Iraqi situation, there can be no hope for building independent organisations when NGOs and other organisations are so closely linked to the political parties in power. As the journalists in the focus group discussion argued, "If NGOs take money from the governed thereby blunting their criticism of the government...This is a process of vicious circle”. This process makes building genuinely independent NGOs or opposition parties difficult: there can be no hope for political watchdogs in the country when not only NGOs but also small parties and tribes are so closely linked with the political parties in power. As a journalist in the focus groups said, this "not only makes NGOs stay silent but also give full praise to the government".

\section{Conclusion}

Four main conclusions can be drawn from this paper. First, the study has shown that clientelism in Iraq is best understood as emerging from the trading of money for political 
support - 'buying affiliations and buying votes'. Such clientelistic relationships in Iraq were characterised by five features: diffuseness, longevity, obligatoriness, dyadic/collective, and reciprocity.

Second, this paper has examined whether the data obtained from fieldwork provided evidence of clientelism in Iraq. The findings of the paper include the fact that at the individual level, clientelism is manifested in offering public sector jobs, ghost jobs, short - term perks, and retirement pensions. The paper then showed how each of these categories operated, demonstrating that although the ties may not cover all five features of clientelism, as long as they cover the main purpose of cliientelism - i.e. trading money for buying political support with some of the significant features of clientelism, they can be classified as clientelism. Clientelism at the individual level entails parties targeting individuals through mainly one-toone interactions, whereas at the organisational level, clientelism is manifested in buying the affiliation of groups, marked by collective bargaining. The latter includes buying the support of NGOs, small parties and famous, religious, and poor families, all of which are characterised by diffuseness, using a wider range of inducements than jobs and welfare benefits.

Third, today clientelism in Iraq is more diffuse than the centralised patronage version during the time of Saddam, in that currently clientelism by political parties in Iraq is operating through the muhasassa system. Also, the version of clientelism current today in Iraq is more fragmented in the sense that through the muhasassa many political parties have greater access to state resources. Clientelistic ties in Iraq are partly caused by the insecurity of the economic and political situation that has plagued Iraq over the last decades, in that people build loyalties with political leaders to improve their economic life. Clientelism through the muhasassa system in Iraq may also be considered a reasonable method for creating order and stability in an otherwise unpredictable environment, characterised by deprivation and insecurity. Thus, this paper suggests that clientelism (through muhasassa) may have some positive value. In the literature, clientelism has almost entirely negative connotations, but the paper has argued that clientelism is for some people a rational response to the economic and political landscape facing them. Also, it could be argued that clientelism is a way of redistributing state resources that widens public access to these resources; that it involves more people in politics; and that it leads citizens to learn about democratic skills, cooperation and familiarity with public policies and laws. 
However, this is not to say that clientelism is a good alternative to democratic processes in Iraq, since only a minority benefit from it. It is more convincing to argue that the negative side of clientelism outweighs the above-mentioned positive effects. The paper shows that clientelism has exacerbated inequality in accessing state resources, and that people who are involved in clientelistic exchange relationships gain a mutual benefit which is private, and this means privatising public resources for the interest of a particular segment of the community. Also, clientelism hampers fair competition in accessing public resources, and in this situation merit, capacity, and professionalism cannot be developed. Finally, clientelism has stunted critical voices in the society by "calming down people". Instead of voters holding to account their representatives, clientelism makes voters accountable to their representatives.

\section{References:}

Al-Janabi, A. Adawla reiaia wadiktatoria [Rentier state and dictatorship]. Baghdad, Beirut, Irbil: Al-Dirashat Al-Iraqi. (2013).

Andersen, Jørgen Juel, and Silje Aslaksen. "Oil and political survival." Journal of Development Economics 100, no. 1 (2013): 89-106.

Auty, Richard M. "The transition from rent-driven growth to skill-driven growth: recent experience of five mineral economies", in Chambers, B., \& Farooq, A. (eds.) Development Policies in Natural Resource Economies (1999): 55-77.

Eifert, Benn, Edward Miguel, and Daniel N. Posner. "Political competition and ethnic identification in Africa." American Journal of Political Science 54, no. 2 (2010): 494-510.

Eisenstadt, S. Shmuel Noah, and Renâe Lemarchand, eds. Political Clientelism: Patronage and Development. Vol. 3. Sage Publications, 1981.

Fjelde, Hanne. "Buying peace? Oil wealth, corruption and civil war, 1985—99." Journal of Peace Research 46, no. 2 (2009): 199-218.

Eifert, Benn, Alan H. Gelb, and Nils Borje Tallroth. The Political Economy of Fiscal Policy and Economic Management in Oil-exporting Countries. Vol. 2899. World Bank, Africa Regional Office, Office of the Chief Economist, 2002.

Grzymala-Busse, Anna. "Beyond clientelism: Incumbent state capture and state formation." Comparative Political Studies 41, no. 4-5 (2008): 638-673.

Hicken, Allen. "Clientelism." Annual Review of Political Science 14 (2011): 289-310. 
Hilgers, Tina, ed. Clientelism in Everyday Latin American Politics. Palgrave Macmillan, 2012.

Hutchcroft, Paul D. "The politics of privilege: assessing the impact of rents, corruption, and clientelism on Third World development." Political Studies 45, no. 3 (1997): 639-658.

Kawata, Jun'ichi, ed. Comparing Political Corruption and Clientelism. Ashgate Publishing, Ltd., 2006.

Kitschelt, Herbert, and Steven I. Wilkinson, eds. Patrons, Clients and Policies: Patterns of Democratic Accountability and Political Competition. Cambridge, Cambridge University Press, 2007.

Landé, Carl H. "Political clientelism in political studies: Retrospect and prospects." International Political Science Review 4, no. 4 (1983): 435-454.

Le Billon, Philippe. "Corruption, reconstruction and oil governance in Iraq." Third World Quarterly 26, no. 4-5 (2005): 685-703.

Lemarchand, Rene, and Keith Legg. "Political clientelism and development: a preliminary analysis." Comparative Politics 4, no. 2 (1972): 149-178.

Lust, Ellen. "Competitive clientelism in the Middle East." Journal of Democracy 20, no. 3 (2009): 122-135.

Montambeault, Françoise. "When clients become collective actors" in Hilgers, T. (ed.) Clientelism in Everyday Latin American Politics, pp. 99-120. Palgrave Macmillan US, 2012.

Muno, Wolfgang. "Conceptualizing and measuring clientelism." Paper presented at the workshop on Neopatrimonialism in Various World Regions, GIGA German Institute of Global and Area Studies, Hamburg. 2010 .

Nichter, Simeon. "Vote buying or turnout buying? Machine politics and the secret ballot." American Political Science Review 102, no. 1 (2008): 19-31.

Robinson, James A., Ragnar Torvik, and Thierry Verdier. "Political foundations of the resource curse." Journal of Development Economics 79, no. 2 (2006): 447-468.

Schaffer, Frederic Charles. "Why study vote buying." Elections for Sale: The Causes and Consequences of Vote Buying. Boulder, Colo,; London: Lynne Rienner, (2007): 1-16.

Scott, James C. "Patron-client politics and political change in Southeast Asia." American Political Science Review 66, no. 1 (1972): 91-113.

Stokes, Susan C. "Political Clientelism" in Boix, C. and.Stokes, Susan C. (eds.) The Oxford Handbook of Comparative Politics. Stokes, S.C. Oxford; New York: Oxford University Press (2007): 605-612.

Tripp, Charles. A History of Iraq. Cambridge, Cambridge University Press, 2000. 
Vicente, Pedro C., and Wantchekon, Leonard. "Clientelism and vote buying: lessons from field experiments in African elections." Oxford Review of Economic Policy 25, no. 2 (2009): 292-305.

Warner, Carolyn M. "Political parties and the opportunity costs of patronage." Party Politics 3, no. 4 (1997): 533-548. 